\title{
An Appraisal of Electoral Malpractice and Violence as an Albatross in Nigerian's Democratic Consolidation
}

\author{
Amaramiro A. Steve, Matthew Enya Nwocha, Igwe Onyebuchi Igwe \\ Faculty of Law, Ebonyi State University, Abakaliki, Nigeria \\ Email: nwochaenyaeni@gmail.com
}

How to cite this paper: Steve, A. A., Nwocha, M. E., \& Igwe, I. O. (2019). An Appraisal of Electoral Malpractice and Violence as an Albatross in Nigerian's Democratic Consolidation. Beijing Law Review, 10, 77-97.

https://doi.org/10.4236/blr.2019.101005

Received: November 21, 2018

Accepted: January 30, 2019

Published: February 2, 2019

Copyright $\odot 2019$ by author(s) and Scientific Research Publishing Inc. This work is licensed under the Creative Commons Attribution International License (CC BY 4.0).

http://creativecommons.org/licenses/by/4.0/

\begin{abstract}
Election offences manifest in all forms of malpractices such as rigging, thuggery, vote buying, often times culminating in violence. These offences had remained an albatross in the Nigerian electoral journeys from the colonial period through the first republic in 1960 till 1999 when Nigerians started witnessing an untruncated democratic journey in her electoral history. Nigeria's elections have always been marred by electoral malpractices and violence thereby shortchanging the citizens' will and mandate expressed during elections. The general aim of this paper is to evaluate the impact of electoral violence and malpractices on the outcome of elections in Nigeria while the specific objective is to determine the solutions to this malaise for a better democracy based on popular elections in the country. The paper adopts a theoretical, doctrinal and conceptual method of research and utilizes Nigeria's electoral laws, court decisions, as well as legislations criminalizing electoral malpractice and violence so as to arrive at a balanced and objective analysis. The paper found, among other things, that the electoral violence, thuggery and other malpractices have not abated since the new democratic culture in 1999 till date as malpractices and violence have been widely reported in all the States of the Federation in virtually all the elections from Local Government Council to Presidential elections. It is worrisome, even as the courts have showed that elections in Nigerians are a very emotional and quarrelsome matter. It is a matter where Nigerians fight to finish. In spite of its enactment into the Nigerian Electoral Laws, malpractices and violence have not abated, but rather increased. The paper therefore recommends the setting up of Constitutional or Electoral Offences Court to try and punish perpetrators of election malpractices and violence. In addition, the legislature should strengthen the provisions relating to malpractices and violence in the Electoral Act in order to punish those who breach the law whether they are agents or
\end{abstract}


principal actors without favoring any political party, religious, ethnic or any other biases.

\section{Keywords}

Election, Democracy, Malpractice, Violence and Consolidation

\section{Introduction}

The word "Electoral Malpractice" which encapsulates an "offence" is not capable of precise definition. Nwabueze, in attempting a definition stated that "electoral malpractice" constitutes criminal offence under the Electoral Act (Nwabueze, 2003). He also stated that the word "electoral malpractice" connotes "illegal act done with a corrupt, fraudulent or sinister intention to influence the election in favor of a candidate". Hence, in Sadu Malumfashi vs. Usman Yaba and Ors, Rowland, JCA (as he then was) stated that electoral malpractice can occur in a situation where the votes scored by the parties exceed the number of accredited voters. Following from these definitions, where it can be shown that there were discrepancies in the figure between accredited voters on the queue to vote, and the total scores of both parties in the said polling stations or where the results in various polling stations within a constituency are characterized by irregularities due to discrepancy in the number of registered voters and total scores of the two contestants, the courts will have no difficulty in declaring that there is an electoral malpractice. Thus, a situation where the votes scored by both parties at the election exceeded the number of the accredited voters on the queue is as much an electoral malpractice as the case of the total votes case to both parties exceeding the number of accredited voters for the accreditation of voters and the actual voting are only the extreme sign posts for determining whether malpractice has occurred. In between these two extreme sign posts is the situation where votes casts exceed the number of accredited voters on the queue. Generally, electoral malpractices constitute criminal offences. They are listed in the various Electoral Acts and are required to be proved beyond reasonable doubt under the Evidence Law. However, the authors are concerned primarily with electoral bribery and conspiracy; undue influence; corruption; vote buying and Treating, Rigging and Violence.

\section{Theories on Democracy and Elections}

Democracy or simply put, "rule by the people" is an egalitarian form of government, in which all the citizens of a nation determine public policy, the laws, and the action of their state together, requiring that all citizens have an equal opportunity to express their opinion. Democracy is classified in terms. It is a system of government in which citizens give terms of political leaders the right to rule in periodic elections. This is known as minimalism. Direct democracy holds that citizens should participate directly in making laws and policies, and not to do so 
through their representatives. Radical democracy is based on the ideal that there are hierarchical and oppressive power relations that exist in society while deliberative or discursive democracy is a form of democracy in which deliberation is central to decision making. In determining a democratic process, the voting public takes part in elections that lead to the choosing of politicians that represent them in parliament or in the executive arm. Thus, one vital element of democratic theory is "election" which according to Momoli and Adejumobi (2007) serve as an instrument of legitimization for the state and those who manage the reins of state power, while on the other hand, they ensure political accountability to the people. To Nwabueze (1993), it is more comprehensive form of a democratic system that entails the selection of people into positions of leadership. It is thus the theory of legitimacy that underscores the necessity for elections in a political democracy.

In moral philosophy, "legitimacy" is often positively interpreted as the normative status conferred by a governed people upon their governor's institutions, offices, and action based upon the belief that their government's actions are appropriate uses of power by a legally constituted government. In other words, government is not legitimate unless it is carried on with the consent of the governed. Legitimacy usually is understood as the popular acceptance and recognition by the public of the authority of a governing regime, whereby authority has political power through consent and mutual understandings, not coercion. It is seeing as the manner of choice agreed upon by a group of people which enables them select one or few people out of many to occupy one or a number of authority positions. Thus, whereas election is a process of selection, legitimacy, which is inherent in election confers consent, acceptance, recognition and authority to the elected, and the struggle for power is an important index in elections and its legitimization. The writers consider the theory of legitimacy as an important complement to the quest for power and the theory of democracy, which should not be subverted through election malpractices and violence.

\section{Bribery and Conspiracy}

Official security agencies, including the police, army and state security services, face a considerable challenge in maintaining law and order during the electoral process, particularly the campaign, voting, and counting periods which are often marred by bribery and conspiracy. The duo can be described as pervasive during the electoral process. Bribery and conspiracy remains one of the most obnoxious corrupt practices. Bribery, for the purpose of election can be committed by a person directly or indirectly by himself or by any other person on his behalf. It is interesting to note that the law in Nigeria provide for instances where a gift or offer is made even to a community as constituting bribery and can be committed even before an election. For bribery to be established in electoral process, it must be clear that the gift, loan, offer and promise must be made for purposes of inducing any voter to vote or refrain from voting at any election. And by virtue of section 124 of the Electoral Act 2010, it is clear that the offence of bribery can be 
committed even before an election. For bribery to be established in electoral process, it must be clear that the gift, loan, offer and promise must be made for purposes of inducing any voter to vote or refrain from voting at any election. This was the attitude of the Pakistani Judiciary in a host of other cases. ${ }^{1}$ It is not clear whether a promise by a candidate at such meetings can ever constitute the offence of bribery in Nigeria. It is interesting to note that an election has been declared invalid in Nigeria because the candidate committed an offence of bribery. ${ }^{2}$

However, the Electoral Act provides that any person who does any of the following: directly or indirectly by himself or by any other person on his behalf, gives, lends or agrees to give or lend, or offers nay money or valuable consideration; or directly or indirectly, by himself or by any other person on his behalf, corruptly makes any gift, loan, offer, promise, procurement or agreement to or for any person, in order to induce such person to procure or to endeavor to procure the return of any person as a member of a legislative house or to an elective office or the vote of any voter at any election; or upon or in consequence of any gift, loan, offer, promise, procurement or agreement corruptly procures, or engages or promises or endeavors to procure, the return of any person as a member of a legislative house or to an elective office or the vote of any voter at any election; or advances or pays or causes to be paid any money to or for the use of any other person, with the intent that such money or any part thereof shall be expended in bribery at any election, or who knowingly pays or causes to be paid any money to any person in discharge or repayment of any money wholly or in part expended in bribery at any election; or after any election directly, or indirectly, by himself, or by any other person on his behalf receives any money or valuable consideration on account of any person having voted or refrained from voting, or having induced any person to vote or refrain from voting or having induced any candidate to refrain from canvassing for votes for himself at any such election, commits an offence and on conviction shall be liable to a maximum fine of N500,000 or 12 months imprisonment or both.

A voter commits the offences of bribery under the Electoral Act where before or during an election directly or indirectly himself or by any other person on his behalf, receives, agrees or contracts for any money, gift, loan, or valuable consideration, office, place or employment, for himself, or for any other person, for voting or agreeing to vote or for refraining or agreeing to refrain from voting at any such election. Nothing in the Electoral Act shall extend or apply to money paid or agreed to be paid for or on account of any lawful expenses bonfires incurred at or concerning any election. Also any person who commits the offence of bribery is liable on conviction to a maximum fine of N500,000 or imprisonment for 12 months or both. And any person who conspires, aids or abets any

${ }^{1}$ See Swaminatha vs. Ramadingam (1958) 14 ELR 3383: or (1952) ELR 390 at 395-6: Karia vs. Frederick (1958) ELR 403.

${ }^{2}$ This was the position in Nwagboga Alo vs. Nwankwo. (1966) 6 ENCL 99. One salient aspect of this case was that only one witness was called on behalf of the petitioner. 
other person to commit any of the offence under the Electoral Act shall be guilty of the same offence and punishment thereto. For the purposes of the Electoral Act, a candidate shall be deemed to have committed an offence if it was committed with his knowledge and consent or the knowledge and consent of a person who is acting under the general or special authority of the candidate with reference to the election. ${ }^{3}$

\section{Undue Influence}

The import of this problem is evidenced in section 103, Electoral Act 2010 (as amended) providing that a person who corruptly by himself or by any other person at any time after the date of an election has been announced, directly or indirectly gives or provides or pays money to or any person for the purpose of corruptly influencing that person or any other person to vote or refrain from voting at such election, or on account of such person or any other person having voted or refrained from voting at such election; or being a voter, corruptly accepts or takes money or any other inducement, commits an offence and is liable on conviction to a fine or imprisonment for a term of 12 months or both. This law also incorporates threat or violence as a fundamental element of electoral violence. The court attaches great importance to the actual words spoken in determining the seriousness of a threat. In the case of Jagan Brasad v. krishnadatt, ${ }^{4}$ it was alleged that a ruling prince who commanded great influence, among the Jat tribe said in a public meeting that those who voted for the appellant "would go to hell". The court held that the words "go to hell" as used in the context amounted to a threat and as a result the exercise of undue influence on the voters. Proof of threat that will culminate to undue influence is conclusive once the method of inducement adopted conveys to the mind of the person addressed that no compliance with the wishes of the person offering the inducement ${ }^{5}$ may result in physical or spiritual harm to himself or to any other person in whom he is interested. Temporal undue influence can assume the shape of threat of dismissal from a lucrative employment or threat of eviction of a tenant. Under exercise of spiritual influence is statutorily prohibited. This is not restricted to priests but extends to Muslim religious leaders and traditional rulers capable of exercising spiritual influence over their subject.

In the case of Fagbe vs. Etchie, ${ }^{6}$ corrupt practices were alleged on the part of Olu of Warri and not to vote for the petitioner who belonged to the opposing party. The petitioner alleged that in order to achieve the desired result, the Olu set out his chiefs with instructions to invoke the wrath of the Itsekiri tribal god on any Itsekiri, voting for the petitioner or failing to vote for the respondent. According to the petitioner, the chiefs carried out these instructions and the invocations operated in the minds of the illiterate villagers in such a way as to de-

${ }^{3}$ See section 124 of the Electoral Act 2010.

${ }^{4}(1959) 20$ E.L.R. 443 at 468.

${ }^{5}$ R. vs. Barnwell (1957) 29 L. T.O.S. 107. Also see the Wareham Case (1857) 29L.T.O.S. 346

${ }^{6}(1955)$ WNLR 134. 
prive them of any will to freely exercise their choice. Onyeama Ag. Judge (as he then was) dismissed the petition for want of proof of agency between the Olu of Warri and the respondent. The same decision was reached in the case of $\mathrm{Ku}$ beinje vs. Edukugho ${ }^{7}$ where again the Olu of Warri was alleged to have exercised undue influence. These cases, however, have proved sufficient authority to the fact that traditional rulers exercise some spiritual influence over their subjects. Further, the law considers as undue influence an exercise of temporal or spiritual influence, which results in damage, harm or loss upon or against any person. By virtue of the Electoral law, ${ }^{8}$ a person is guilty of undue influence if the abduction, duress or any fraudulent device or contrivance, he impedes or prevents the free use of the vote. Abduction is not defined in the statute. The dictionary meaning of the word "abduct" is to kidnap or take away by illegal force or fraud. In the context of election, such abduction must be geared towards impeding the free exercise of franchise ${ }^{9}$. Fraudulent device and contrivance as constituents of undue influence are not popular means of challenging elections, hence, the paucity of case law. Therefore, in order to prove the offence of undue influence based on any such device or contrivance, fraudulent intent must of necessity be established. ${ }^{10}$ Undue influence obtains generally where a person directly or indirectly or by any other person on his behalf, makes use of or threatens to make use of any force, violence or restraint, or who inflicts or threatens to inflict by himself or by any other person, any temporal or spiritual injury, damage, harm or loss on or against any person in order to induce or compel that person to vote or refrain from voting or on account of such person having voted or refrained from voting at an election. Furthermore, it may arise from someone who by abduction, duress or any fraudulent device or contrivance impedes or prevents the free use of the vote by a voter or thereby compels, induces or prevails upon any voter either to give or refrain from giving his vote. It also includes all forms of physical, temporal or spiritual influence with a view to affecting the free exercise of the franchise directly or indirectly.

However, it must be observed that the use of the adjective "undue" to qualify the word "influence" suggests that not all kinds of influence are prohibited by law. ${ }^{11}$ In Nigeria, apart from religious leaders of different persuasions, there abound other persons capable of exerting undue influence. They include traditional rulers, employers of labour, landlords and functionaries of the government in power. Apart from actual use of force or evidence, a threat of force or violence is equally an offence under the electoral law. ${ }^{12} \mathrm{~A}$ threat of violence must be deliberately uttered with the intention of carrying it into effect and not in a moment of anger. In other words, the threat must be serious. It is immaterial whether the 
person using the threat had the power to carry it out or not. Besides the threat, use of force and violence must be directed at the person. The court attaches great importance to the actual words spoken in determining the seriousness of a threat. Furthermore, it may be said that abduction and duress can equally be classified as fraudulent devices or contrivance. It is important to note that the words "contrivance" and device are qualified by the word "fraudulent". However, in parimaterial, the Electoral Act detailed the offence as any person who corruptly by himself or by any other person at any time after the date of an election has been announced, directly or indirectly gives or provides or pays money to or for any person for the purpose of corruptly influencing that person or any other person to vote or refrain from voting at such election, or on account of such person or any person having voted or refrained from voting at such election; or being a voter, corruptly accepts or takes money or any other inducement during any of the period stated in paragraph (a) of this section, commits an offence and is liable on conviction to a fine of $\mathrm{N} 100,000$ or 12 months imprisonment or both. $^{13}$

\section{Offences Bordering on Corruption}

Simply put, corruption is the involvement in illegal, dishonest or wicked behavior which is destructive of the moral fabric of society and devastating to the economic well-being of a nation. Corruption is a catalyst to financial and economic crimes in contemporary Nigeria. It includes bribery, fraud and other related offences. ${ }^{14}$ One of the earliest enactments against corruption is in the area of electoral offence. Corrupt practices in the electoral process are indeed as old as the practice of democracy in the world. The offences are usually characterized and defined. ${ }^{15}$ Corrupt practices in the electoral process are prevalent during registration of voters exercise and in the course of campaigning. A register of electors is an official list of the persons who are entitled to vote in the election to which the list relates, and the process of compilation of registers known as the registration of electors or registration of voters. ${ }^{16}$ Corruption during registration of voters can occur either by willful refusal to register qualified electors in given locations with the sole intention of disenfranchising them (which is to the obvious advantage of the opponent) or by the deliberate inflation of the register in a given constituency. This occurs when money has been given to the registration officer by member of the opposing party or by prospective candidates. The law recognizes the possibility of criminal liabilities resulting from proven cases of corruption on the part of the registration officer. Given the enactment of the Corrupt Practices and other Related Offence Act 2001, the dragnet in Nigeria is now wide enough to check such corrupt practices both from the point of view of

\footnotetext{
${ }^{13}$ See section 130 of the Electoral Act.

${ }^{14}$ See the definition of corruption under The Corrupt Practices and Other Related Offences Act, 2000.

${ }^{15}$ See the Representative of the Peoples Act 1906. Also see the Electoral Acts $f$ Nigeria. See Ujo, supra no 3 at pp. 21-27.

${ }^{16}$ Registration of Voters in the United States, the Brooklyn Institution, Washington DC, USA, 1929.
} 
the receiver and the giver. Corrupt practices in the course of campaigning for an election is the most pronounced form of corruption in the electoral process. Corrupt practices during campaign are aimed at a definite result, and that is getting the voters to cast their vote for the candidate.

\section{Vote Buying and Treating}

According to Adetula (2008), in Nigeria and several other African countries, elections are far from being free and fair, and one of the palpable factors is the menace of vote buying. The malady of vote buying is indeed pervasive in Nigeria as Davies observed that paradoxically, money itself has become a dominant and seems to have taken the centre stage in the political process in most countries and in Nigerian politics. Adetula (2008) again contends that vote buying is a corrupt act which usually takes the form of a gift or gratuity bestowed for the purpose of influencing the action or conduct of the receiver, especially money or any valuable consideration given or promised for the betrayal of a trust or the corrupt performance of an allotted duty, as to a fiduciary agent, a judge, legislator or other public officer, a witness or a voter. As a corrupt act, vote buying can be defined as any form of persuasion in which financial gain is suggested by one person to another with the intention of influencing a person's vote. This includes not only the payment of a simple bribe, but also the payment of excessive traveling expenses and the payments of excessive election workers. Sections 24 and 23 of Electoral Acts 2006 and 2010 respectively defined vote buying as selling or attempting to sell any voter's card whether issued in the name of any voter or not; or buying or offering to buy any voters card whether on the buyer's behalf or on behalf or any other person. Similarly, under sections 131 and 124 of Electoral Acts 2006 and 2010 (as amended), titled Prohibition of Bribery and Conspiracy, the Act outlines the following actions as vote buying: direct or indirect offering or aiding in offering inducement in any form whether to a person or a political campaign for the purpose of corruptly influencing that person or any other person to support or refrain from supporting a political party or candidate; direct or indirect giving offering to give any money or valuable consideration top any person during a political campaign in other to induce that person or any other person to support or refrain from supporting a political candidate; and accepting any inducement, money or valuable consideration from any person, candidate or political party in order to compel that person or any other person to support or refrain from support a political party or candidate. According to Adetula (2008), the actors who buy votes in Nigeria include patrons (godfathers) in the political system; political parties, which could be in the ruling or opposition parties and individual politicians at local government council, state and at national levels. Vote buying occurs when competition for power amongst contending political groups is stiff. This is when the balance of power within the constituency is nearly equal. One or both groups may be engaged in vote buying and buyer of voter are motivated by the factors of capturing state 
power, maintaining authoritarian control of political office and keeping the opposition out of power. Nugent (2001) noted that in most African countries the incumbents certainly enjoyed an enormous advantage by virtue of their control of the financial purse strings. This enabled them to offer voters certain material inducements in return for their compliance on polling day. "Be that as it may, "vote buying was always a second-best strategy, the winning side engaging in straight forward vote buying" (Nugent, 2005). Politics in Nigeria is seen by ruling elites as the only "viable industry" in the country. This is why Kyari contends that politics is a means for self-service in Nigeria today, it has also become the surest, quickest, easiest and most rewarding avenue for escaping the gnawing poverty to which most Nigerians are today condemned. First it requires no training, no capital to initiate a political career in Nigeria in the first instance. You need a string jaw, a capable pair of legs, and a godfather. Strong atavistic instinct, cynical attitude to Nigeria's development and willingness to stand behind your godfather will not only complete the list of quantities you need, but would also accredit you to the winning party of the times. Politics is not a matter of issues or ideology, but simply of the stomach as its most successful practitioners would readily tell you. Thus, the sellers of votes are pushed into this act either because of poverty or as a method of getting part of the national cake. Nugent (2001) concludes that the concomitant effect of vote buying in electoral contests in the words of a politician is that "elections are not for the poor. It is extremely expensive enterprise, very expensive". Political bribery involves a situation where persuasion income is channeled and also the attitude of the voter to his vote preference is commercial. In this wise, voters are approached in public houses, and at home and would be offered financial rewards if they voted for the right candidate. Vote buying takes place during registration of voter where registration officers sold empty or completed voters cards to politicians of opposing camps. In 2002, the Transition Monitoring Group ${ }^{17}$ reported cases of vote buying nationwide during the 2002 voter registration. Vote buying is largely illegal, criminal and unconstitutional. It has tremendous impact on the process of transitioning to democracy and Adetula $(2008)^{18}$ lists them viz: it promotes the primacy of money in politics to the detriment of merit, ideology and free and fair competitive political competition. The character and quality of persons seeking mandates are not questioned. In addition, there has been a disappearance from political praxis, debates and ideas and issues affecting the populace. Old and unproductive politicians are recycled into political process to the extent that such individuals are only concern with personal projects and primitive accumulation of wealth. Vote buying therefore obstructs the consolidation of democracy in $\mathrm{Ni}$ geria because of the ultra-privatization of transition project by money bags, political instability due to recurring electoral and political violence amongst political groups. Vote buying promotes elitist politics and weakens popular participation.

${ }^{17}$ TMG Report in Kwara and Rivers States etc in Dung P. S., op.cit.

${ }^{18}$ Adetula, op.cit. 
Only persons with resources get access to political offices in Nigeria. Communities with grassroots solidarities hardly have access to political power because of their inability to participate actively in monetized political system. The political parties that bought votes monopolize power to the exclusion of financially weak parties. They become new autocrats in the political process and consequently become disconnected from people (Abatudu \& Obakhedo 2009). Again, political institutions (National Assembly, State Assemblies and Government Houses in Nigeria's for instance) are inhabited by some politicians with stolen mandates through vote buying. These affect the image and respects for such national institutions and ultimately have a devastating impact on the legitimacy of such institutions.

Finally, administrations that have forcefully come to power through vote buying spend considerable time recouping from its political investment, usually through the pilfering of state resources. Consequently, little resources are available for the fulfillment of campaign promises and peoples' livelihood expectation. Worse still, little attention is paid to the development of democracy.

\section{Electoral Rigging}

Nwabueze (2003) aptly described election rigging as "electoral malpractices which are palpable illegalities committed with a corrupt, fraudulent or sinister intention to influence an election in favor of a candidate(s) by means such as illegal voting, bribery, treating and undue influence, intimidation and other acts of coercion exerted on voters, falsification of results, fraudulent announcement of a losing candidates as winner (without altering the recorded results). Election rigging is another stooge; a criminal conduct of subverting an entire electoral process through a massive organized fraud with the active participation of officials of the electoral body. The objective of rigging or fraud is to frustrate the democratic aspirations of citizens who have voted, or would have voted into office someone other than the rigged in individual.

There are three phases (forms) in election rigging; pre-election, Election Day and post election rigging (Ibrahim \& Aturu, 2009). Pre-election rigging involves the manipulation of the system elaborately. Many political forces in Nigeria do not get a chance to participate in elections because the conditions for party registration are such that groups could be denied the right to establish the party they desired to contest for power with. During the run up to the Second Republic for example, 150 parties were established and the electoral umpire came up with stiff conditions for registration that stultified the ambitions, hence, they were forced to merge and at the end of the day, only 18 parties were able to meet the requirements and submit their application forms, out of which the State only registered five political parties. Furthermore, the constitution did not provide for independent candidates as they were banned from contesting elections. Ibrahim and Aturu (2009) submit that this party system created conditions for rigging out strong individual candidates that could have got into power as independent 
candidates through the respect they invoke in their communities. It also rigged out ideologically committed people such as socialist who did not have the financial resource and network to establish mega parties but have a long term transformative vision. Furthermore, it rigged out the minority groups who do not have numbers and networks of majority groups to impose their registration on the state.

Another form of pre-election rigging is the manipulation of the voters register. In Nigeria, we have a history of the illegal acquisition of voter's cards by some parties and its purpose is to create conditions for the over-registration of certain persons and groups and simultaneous under-registration of other persons and groups, while favored groups have their votes multiplied others are basically disenfranchised. This involves buying over electoral officials and or getting party supporters appointed as electoral officers so that they would tamper with the electoral process to produce a desired outcome. Again, nomination during party primaries and gerrymandering are other forms. Interestingly, many candidates are denied the right of contesting elections because they are prevented from contesting for their party's nomination. Gerrymandering as a pre-election rigging tool involves manipulation while drawing the boundaries of electoral districts to favor some political parties and candidates while scheming out others. Election Day or Polling Day rigging on the other hand, entails the collaboration between polling officials and agents to subvert the electoral rules, stuffing of ballot boxes, under-aged voting, delay in opening polling centre located in opposition strongholds, late or non supply of election materials to opposition strongholds, multiple voting, inducement of voters with food and money and threatening voters with use of force.

Nwabueze (2003) states that election rigging is a notorious fact both in its incidence and in the forms it takes as now to constitute the most serious problem confronting democracy in Nigeria. Its principal forms, perfected by successive elections since 1964, 1965, 1979, 1983, 1999 and 2003 are well known: dumping of ballot boxes stuffed with pre-thumb-printed ballot papers; falsification of results by increasing a candidate's votes and decreasing those of his opponents, fraudulent announcement of a losing candidates as winner. Continuing, he said, that the key agents in the dumping of ballot papers are the presiding officers and poll clerk at the polling stations. Their active cooperation is needed before thumb-marked ballot paper can be dumped into the ballot box in use at the polling station or before a ballot box stuffed with thumb marked ballot paper can be brought to the polling station and exchanged for the ones in use there. And the ballot papers to be used for the purpose would have to come from the presiding officer if their serial numbers are to agree with those issued to the polling station, though often ballot papers not in the series are used. In many cases, the presiding officers and poll clerks go beyond merely supplying ballot paper and allowing them to be dumped or allowing ballot boxes to be exchanged, and actually take part in the thumb-marking of ballot paper at a fixed rate for a given 
number of ballot papers so thumb-marked. In contrast, post election rigging are incidented by refusal to count ballot papers from opposition strongholds; changing the results between voting centers and collation centers; declaration of false results; annulment of elections in situations where incumbents believe the results, the people's choice are unacceptable to them and long delays or manipulation of election tribunals to protect stolen mandates.

Generally, therefore, rigging could be by stuffing of the ballot box with fake ballot papers before the Election Day or on the Election Day; falsification of results and forgery of figures both at polling units and collation centers; or voting by unregistered person and publication of false statement of the withdrawal of a candidate. Constructive ways of rigging elections include creating artificial scarcity of ballot paper in "safe" polling booths of the opponents, diversion or snatching of ballot boxes between polling booths and counting centers and abduction of returning officers. All these actions are usually perpetrated for gratification (Umaru, 2003). Rigging an election remains the single most incendiary malpractice that can throw the entire election process into violent upheaval. In Nigeria's experience, there were occasions when announcement revealed as winners, candidates completely outside the expectations of the majority of the electorate. On such occasion, immediate blow up and tumult can occur at the very point of collation and declaration of results. One interesting case was the case of Ondo State gubernatorial election in 1983 where the NPN candidates, Chief Akin Omoboriowo were declared elected by the Electoral Commission against Chief Michael Ajasin of UPN, who actually won the election. Chief Omoboriowo's results were actually inflated while that of Chief Ajasin was decreased (Eze, 1984).

Electoral rigging has been perpetrated with such masterly deftness that they have become an art. The perpetrators have continued to out-manoeuvre opponents through their considerable skills in creating new forms in addition to the old forms. These new forms include declaration of results without holding election. In 2007, in the states of Bayelsa and Cross River, in many polling units, there were no balloting, yet election results were declared. The Court of Appeal found in both cases that forms EC8A were not available indicating that no elections were held across the two states. Also, non-serialization of ballot papers is new forms of electoral rigging. Section 45 Electoral Act 2006 provides that ballot papers shall be bound in booklets and numbered serially with differentiating colours for each office being contested. In 2007 presidential elections, INEC conducted elections without complying with this mandatory statutory provision. According to INEC, this lapse was occasioned by the last minute ruling by the Supreme Court that INEC should add Alhaji Atiku Abubakar, the Action Congress presidential candidate on the ballot, close to the date fixed for election. The Court of Appeal in its judgment on the issue upon the petition of Alhaji Atiku Abubakar, agreed that the non-serialization was indeed an act of non-compliance with the provision of the Electoral Act, 2006 but that the non compliance was 
not substantial enough to warrant a nullification of the presidential election. Similar to this new art is the tendentious public holidays and banning of campaigns. Shortly, before the Supreme Court gave its decision on the challenge by Atiku Abubakar of his exclusion by INEC from the presidential election, the PDP controlled federal government gave unexpectedly a public holiday to coincide with the date scheduled for judgment by the apex court. The holding was aimed at frustrating the AC candidates and to confirm this fear, the Inspector General of Police at the time banned the candidates from further campaign shortly after the judgments, thus, ensuring that although Atiku Abubakar won the court case he was unable to campaign effectively or at all.

Finally, the deceptive arrangement of candidates" logos on ballot papers speaks volume of the umpires" compromise in election process. In a transparent process, the ballot papers to be used for any election ought to have been sighted by the candidates or their parties. This would enable the contestants to educate their illiterate voters on how to vote. This was not the case in the States of Adamawa and Lagos, for example, where in a re-run election in Adamawa State; the Action Congress candidate party logo was, inserted so close to that of another party that did not contest the election. The end result was that voters were voting in the middle of the spaces for the two parties leading to a situation where there were more voided votes in that election. In a similar manner, Mr. Jimi Agbaje, a gubernatorial candidate of DPA complained that his party's logo was not included in the ballot paper for the 2007 governorship election (Ibrahim \& Aturu, 2009). Complaints in this form do not only raise the question of fairness of the electoral umpire but also in the contrary point out the other forms of rigging in electoral process.

The disastrous consequences of election rigging to democracy and electoral process were summarized by Nwabueze (2003). According to him, rigging deprives elections of their essential purpose as popular basis for government. A government which by electoral malpractice keeps itself in office against the votes of the majority of the electorate lacks the legitimacy of the moral authority that popular mandate bestows. Secondly, election rigging undermines another cardinal principle of democracy; the principle that the welfare of the people being the object of government, victory at an election must be related and linked to ability to secure and promote the people's welfare, and that a government which has not performed well in this forfeits all claims to have its mandate renewed. This principle postulates elections as the people's ultimate and most effective weapon for enforcing a government's responsibility and accountability to it. Thirdly, from the stand point of the political parties and their candidates, rigging, deprives election of its character as a competition in which all the contestants can equally aspire to win. Where the capacity of the contestants to rig is vastly unequally because one of them is in a position of irresistible influence over the electoral body and has power of control and direction over the organized coercive force of the country represented by the police as well as vastly greater 
resource of money and patronage, then the other contestants have no real chances of winning. An election contest in which the result is not determined by the votes lawfully cast for the contestants but by fraudulent manipulation is a mocking of the very idea of a competition.

The implications that follow from this factor are that a political party with no chance of ever winning will have lost the raison d'etre for its existence. Sooner or later it will fade away through its members defecting to the ruling party as the hazards of opposition weigh more heavily upon them. Again, when because of rigging, elections become unavailing as a means of changing a government, violence, with a possible break down of law and order, might result. Wholesale and brazen election rigging seems to attract violent disturbances almost as an inevitable reaction. Propper (2003) in underscoring the cardinal importance of mass action in a democracy said that "the working of democracy rests largely upon the understanding that a government which attempts to misuse its powers and to establish itself as a tyranny (or which tolerates the establishment of tyranny against anybody else) out laws itself, and the citizens have not only the right but also a duty to consider the action of such a government as a crime, and its members as a dangerous gang of criminals".

\section{Electoral Violence}

The Encarta Dictionary defined the word "electoral" as "relating to or involving elections, electors or voters", while violence is the use of physical force to injure somebody or damage something."The laws bordering on Electoral offences and malpractices fall within sections 124-139 of the Electoral Act 2010 and similarly, in section 117-132, Electoral Act 2006. To Oshiomhole (2011), electoral violence is any violence that is calculated and orchestrated to affect the outcome of elections. It may well include the use of thugs, ballot snatching or harassment of voters or opponents. In agreeing with the elements of all the definitions ${ }^{19}$, the Electoral Reform Committee Report states that electoral violence refers to the use or threat of force against an opponent within the context of electoral competition for state power. Electoral violence is inhibitive of democratic transition and consolidation. Violence has been a feature of the country's electoral process since the colonial era (Omotola, 2007). During this period, violence was easily curtailed due to the nature and scope of participation, characteristics of politicians and electorates and the nature of colonial domination. After independence, up to the 3rd republic, electoral violence has remained an instrument for intense struggle for power among politicians (Nwolisa, 2007), with the Nigerian youths intensively involved in electoral violence manifesting in thuggery and hijacking of materials. Electoral violence manifests in three electoral stages, namely pre-election, during election and post-election. To Oshiomhole (2011), electoral violence has three forms namely: violence unleashed by individuals or at instance of individuals to forcefully ensure that the electoral process is in their fa-

\footnotetext{
${ }^{19}$ Electoral Reform Committee Report, vol. 1, 2008, p.19.
} 
vor or in the favor of their parties, their godfathers or their cronies. This may take a variety of forms, including assassination, use of thugs; ballot snatching etc. There is also the structural dimension in which the state through its custodians applies violence to tilt the political balance in their favor or simply to overwhelm the electorate into accepting a predetermined outcome. The third form of violence is popular resistance to the manipulation of the electoral process or illegitimate protest of election rigging.

Electoral violence in Nigeria is primarily due to the perception of politics and political office as investment and as avenue for the acquisition of extra ordinary wealth through corruption, which is otherwise not possible through any form of legitimate vocation and enterprise. As a result of this perception, and reality, Alemika (2011) posits that Nigerian politicians turn electioneering and elections into warfare in which violence and ethnic, religious and other forms of primordial sentiments and prejudices are employed. Similarly, Dudley (1961) observed that the shortest cut to affluence and influence is through politics. Politics means money and money means politics... to be a member of government party means avenue to government patronage, contract deals and the like. Once the politicians recognize or know the profitability of having power, the party (and the individual members) naturally uses the same governmental machinery to stay in power. The leadership becomes self-recruiting oligarchy and no self-recruiting oligarchy has been known to tolerate opposition to itself. In the circumstance, violence becomes instrument for seeking, gaining and retaining political power. Nigerian political parties and politicians employ fraudulent and violent means to win election. The Political Bureau ${ }^{20}$ in 1987 reported that Nigerian politicians and parties rigged elections "in most blatant fashion... violence, corruption, arson and brigandage were employed in the mad desire to win and retain power both in the region and at the centre". Similarly, the Constitution Drafting Committee ${ }^{21}$ observed that the country's politics is primarily geared towards securing "opportunity to acquire wealth and prestige, to be able to distribute benefits in the form of jobs, contracts, scholarship, and gifts of money and so on to one's relatives and political allies and cronies.

Poverty is the state of being extremely poor. It is a situation whereby an individual cannot meet the basic needs of life, such a person is more likely to participate in violence than a rich person in line with relative deprivation theory, and when the situation is compounded by the youth bulge, the propensity for violence increase. The army of unemployed youths has continued to increase, hence, a tool for electoral violence. The violence in Edo, Bauchi, Katsina and Osun States in 2003 and 2007 general elections had been attributed to this factor. The ineffectiveness of security forces cum culture of impunity of the security apparatus helps to worsen the situation. During the pre-election stage of the 2003 elections, a number of politicians were murdered. The police have been

${ }^{20}$ Report of the Political Bureau, 1987, 25.

${ }^{21}$ Report of the Constitution Drafting Committee, vol. 1, 1976, 98. 
unable to get to the root of these killings. The failures of police to unveil the killers have created a culture of impunity and motivation for recurrence of the crime. In Nigeria, there are no specific legislations against certain electoral offences, beyond monetary fines, but only for associated acts like arson, assault and murder. The electoral laws have no provision for the snatching of electoral boxes from polling booths. Moreover, the penalties for acts associated with electoral violence, like arson and assault are generally weak, a few years of imprisonment at most. This has greatly contributed to the culture of impunity that pervades the elections.

The Norwegian Sociologist, John Galtung (1960) in the 1960's, defined structural violence as the systematic ways in which a regime prevents individuals from achieving their full potential. It is a form of violence based on the systemic ways in which a given social structure or social institution harms people by preventing them from meeting their basic needs. Weak governance and corruption are some of the causes of structural violence in Nigeria and they exacerbate the effects of poverty and make people desperate enough to seek any means including crime and violence to survive. Closely related to weak governance is corruption which is entwined with political violence in Nigeria where public revenues are not only stolen, but are often used to pay for the services and weapons used for electoral violence. The last but not the least is the factor of small arms proliferations in Nigeria. According to report, there were over one million illegal small arms reportedly in circulation in Nigeria as at 2004. These weapons were used to perpetuate violent conflict and create new cycles of violence and crime. The effects of electoral violence impinge on political instability, insecurity and cycle of violence (Obateru, 2008). Political instability arises due to inability of opposition to resolve perceived or real grievances. Electoral violence breeds insecurity as it is characterized by loss of lives and properties, for instance, in November 2008, over 500 people were killed, thousands displaced and properties worth billions of Naira were burnt, looted and destroyed during the political violence in Jos. In addition to insecurity, there are attendant costs like increased security votes and the resources spent on repairs of damaged infrastructure.

\section{An Analysis of the Albatross}

The statistics of offences, violence and overall malpractices perpetrated by agents of political parties, politicians, stakeholders, candidates and most ignobly, political godfathers are incredibly enormous since 1964, till date, particularly in the years 1964, 2003 and 2007, among others. At the inception of our nascent democracy in 1999, not many a politician believed that the military were keen and honest to hand over power to civilians. The elections were relatively free from all form of malpractice and violence. Hell was however let loose in 2003 elections when it dawned on many that power had shifted from the military to the civilians and that President Olusegun Obasanjo had successfully caged the military from interference in the politics of Nigeria. The 1964 general election was a sig- 
nificant landmark in the political history of Nigeria. The outcome of the election generated controversies that nearly compromised the unity of Nigeria. Before the election, different political parties in Nigeria had formed alliance that finally coalesced into two main political parties-the United Progressive Grand Alliance (UPGA), which comprised of the NCNC, NEPU, NPF, AG and UMBC, and the Nigeria National Alliance which was made up of NPC, NNDP, MDF, and the NDC. According to Uzoigwe (2007), Nigeria was beset by various problems that seriously threatened its stability. The first was the implosion of Obafemi Awolowo's Action Group Party by 1962 that resulted in the rise of Samuel Akintola and the realignment of political forces in Nigeria. The second was the population enumeration crises of 1962-1963 that pitted the North against the East, while the west remained interestingly quiescent because of the evolving rapprochement under Akintola's leadership with the North. The third was the formal parting of ways between the Northern People's Congress (NPC) and the National Council of Nigeria citizen in 1964. The fourth; was the federal Election of 1964-1965.The 1964 Federal Election was the first post independence election to be held in Nigeria, and was conducted by Nigerians themselves. It was described by Kirk-Green as "the most perilous display of brinkmanship having been held at a time when the country tottered perilously on the brink of disintegration and bloodshed." The 1964 Federal elections was generally characterized by bitterness and acrimony and therefore extremely violent. It was marked by thuggery and hooliganism. There was massive rigging, intimidation, thuggery, vandalism, discrimination, exclusion, denial, manipulation, ethnic jingoism and outright killing of political opponents (Anifowoshe, 1982). Ibrahim and Aturu (2009), cried a loud that the 1983 elections occupy a special place in the history of electoral fraud in Nigeria. Competitive rigging reached its apogee; all sorts of strategies and strategems including manipulation of the ballot or "rigging" were employed in order to win elections. They state that each of the opposition parties used its local power of incumbency to retain power and/or to improve its position vis-à-vis other contenders. However, federal might was used to dislodge state governors in Anambra, Oyo, Kaduna, Gongola and Borno States, thus raising NPN's governorships from seven to twelve states, reversing the power structure existing before the election when opposition parties had twelve against NPN's seven governors. Continuing, Ibrahim and Ibeanu state further that one interesting cases was the Ondo state gubernatorial election in 1983 where the National Party of Nigeria (NPN) candidate, Chief Akin Omoboriowo was declared elected by the electoral commission with 1,228,891 votes as against $1,015,385$ votes credited to the Unity Party of Nigeria (UPN) candidate, Chief Michael Ajasin, whereas the true score, as found by the election courts...were 1,563,327 votes for Chief Ajasin and 703,592 for Chief Omoboriowo. And that Chief Omoboriowos" scores was thus inflated by 523,389 votes while that of Chief Ajasin was decreased by 547,942 votes.

This electoral fraud, committed by the NPN ruling party in favor of Akin 
Omoboriowo, having being declared "elected" moved the irate electorate into action to burn police stations, houses of prominent NPN supporters and killed many a thousand Nigerians. The 1983 elections significantly witnessed a shift from traditional forms of election based on the manipulation of the ballot to total regard of the figures collated on the ballots and completed forms, as figures totally unrelated to any results genuine or forged are simply announced and illegally protected with state power (Smah, 2008). Adetula, successfully compiled some selected cases of electoral violence in Nigeria between 1999 to 2006. In October 20, 1999 Air Cdr Anthony Ikhazoboh (rtd), former Minister of sport was shot in the presence of his wife when assassins trailed him to his Victoria Island home in Lagos. In December 2000, Lai Balogun, a frontline politician was killed by hired assassins at his Lagos residence. In December, 18, Hon. Monday Taurbari Ndor, a member of the Rivers State House of Assembly was dragged out of his car and shot dead by unknown assailants. In November, 2002, Dele Arojo, a PDP governorship candidate in Ogun State was murdered in Lagos and same month, Alhaji Isyaku Mohammed, the United Nigeria People's Party (UNPP) chieftain in Kano State was assassinated in Kano. On December 23, 2002, Chief Bola Ige, Justice Minister and Attorney General of the Federation, was shot dead at his Bodija residence in Ibadan by assassins. On February $8^{\text {th }}$, 2003, Chief Ogbonnaya Uche Ogbonnaya, Orlu Senatorial candidate of ANPP was killed. On $5^{\text {th }}$ March, same year, the South-South Vice Chairman of ANPP, Chief Marshall Sokari Harry was murdered in his Abuja residence by assassins; and on March 21, Mr. Anthony Nwodo, ANPP Secretary in Ezza North Local Government Area of Ebonyi State was murdered. In May 3, Mrs. Joyce Maimuna Katai, Commissioner of Women Affairs and Special Development in Nassarawa State was murdered by suspected party loyalists in the electoral violence that erupted in the Toto Local Government Council. In October, Prof Chimere Ikoku, a PDP chieftain and former vice chancellor of University of Nigeria Nsukka was assassinated buy gun men. On January-March 2004, Chief Amanasoari Dikibo, the PDP National vice Chairman (South-South) was assassinated unknown by gunmen at Asaba road in Delta State among others. The statistics of violence could go on and on, as those assassinated/murdered cut across the segment of the society-politicians, academics, security officers, business men and women, students and so forth. The orgy of electoral violence has not abated once 2006 till date. Flash points of election related violence have been reported in Anambra, Borno, Lagos, Osun and Edo States among others. In Anambra State, Ndigwe (2009) reported that in all the polling booths, electoral materials came very late (as late as $4 \mathrm{pm}$ in some centers) and did not come with result sheets. And that the result sheets had been written up ahead of time. In Borno, Mu'azu reported that during the 2007 elections, there were attempts to seize ballot boxes by political thugs. In Gudumballi and Magumeri local governments areas, violence broke out between rival political parties leading to orchestrated rigging that culminated in the death and injuries of persons at this Local government area respectively. 
In Edo State, Abatudu and Obakhedo (2009) reported that elections in Edo State in 2007 was largely characterized by multiple registration and multiple voting, snatching of ballot boxes preferential allocation of ballot papers, prior distribution of thumb printed ballot papers to voters and stuffing of ballot boxes. Indeed, wide spread violence was visited on the electoral process in the various local governments across Edo State, as thugs invaded polling stations and forcefully took away ballot boxes, ballot booklets and vital electoral materials. At Akoko-Edo, Igarra, Etsako central and Uhunmwodo local government areas of Edo State, intense power contest between PDP and Action Congress led to burning of houses, INEC offices, destruction of properties, and loss of lives. The sad history of electoral fraud, rigging, corruption, thuggery and overall malpractices and violence have serious implications on our democracy because the phenomenon is increasing rather than declining.

\section{Conclusion and Recommendations}

The more we treat the malpractices and violence with kid gloves, partisanship, religious, ethnic and tribal sentimentalities, the more we fail to set up the mechanism to seriously handle the cases, and the more albatross it remains to destroy our electoral processes and fledgling democracy. Political violence is part and parcel of a broader epidemic of violence that has devastated the lives of tens of thousands of Nigerians since the country returned to civilian rule in 1999. Unfortunately, it is the Nigeria youths that have been used to perpetrate this ugly trend. This is contrary to what happens in most "civilized societies where youths are the engine rooms of electoral process. They are actively involved in rallies, campaign and other pre-election actives ... that are devoid of violent confrontation that might result into loss of lives and properties."

According to Ibrahim \& Aturu (2009), the enthronement of democracy in Nigeria since 1999 has opened the floodgate of political and electoral violence that has led to wanton destruction of lives and properties. Violence he maintained was spearheaded by youths sponsored financially, physically, morally and other wise by politicians and political office holders. The pernicious trend is underpinned by money politics as he who pays the piper dictates the tune. The recent election in Ekiti State of Nigeria is an attestation to the massive use of money to influence election and propel malpractice and violence. Today in $\mathrm{Ni}$ geria as in other African States, money politics, vote buying, godfatherism, and "sharing the money are regular household phrases and slogans that have portrayed moral decadence of politicians" (Adetula, 2008). We therefore strongly recommend the urgent establishment of the enforcement mechanism that would handle the cases and malpractices and violence that stems from elections. The "Constitutional" or "Electoral Offences" courts to handle the issues on malpractices should be created urgently. Further the legislature should always strengthen the laws on malpractices while the executive through patriotic and selfless leadership should exercise the strong will to enforce the laws without knowing 
whose ox is gored. In conclusion, we insist as the court did in Ojukwu vs. Onwudiwe $e^{26}$ that the essence of democratic elections is that they be free and fair and that in that atmosphere of freedom, fairness and impartiality, citizens will exercise their freedom of choice of who their representatives shall be by casting their votes in favor of those candidates. The voters must be allowed to freely go to the polling booths and cast their votes unmolestedly. Free and fair election cannot, therefore, tolerate thuggery or violence of any kind; or corrupt practice, impersonation, threatening, undue influence, intimidation, disorderly conduct, and any acts which may have the effect of impeding the free exercise by the voter of his franchise.

\section{Conflicts of Interest}

The authors declare no conflicts of interest regarding the publication of this paper.

\section{References}

Abatudu, M., \& Obakhedo, N. O. (2009). Mandate Theft and Retrieval: The 2007 Governorship Election in Edo State. In J. Ibrahim, \& O. Ibeanu (Eds.), The 2007 Nigerian Elections and Subversion of Popular Sovereignty. Abuja: Center for Democracy and Development.

Adetula, V. A. O. (2008). Money and Politics in Nigeria. Abuja: Petra Digital Press.

Alemika, E. E. (2011). Post Election Violence in Nigeria: Emerging Trend and Lessons. Jos: University of Jos Press.

Anifowoshe, R. (1982). Violence and Politics in Nigeria: The Tiv and Yoruba Experience. Enugu: Nok Publishers.

Dudley, B. (1961). Deepening Democratic Cultures. Princeton: Princeton University Press.

Ibrahim, J., \& Aturu, B. (2009). Rigging and Electoral Fraud in Nigeria: State of the Art. In J. Ibrahim, \& O. Ibeanu (Eds.), The 2007 Nigeria Elections and Subversion of Popular Sovereignty. Abuja: Centre for Democratic Development.

Momoli, A., \& Adejumobi, S. (2007). The Nigerian Military and the Crisis of Democratic Transition. Lagos, Civil Liberties Organization, Electoral Journal, 1.

Ndigwe, R. (2009). The Debacle: Direct Capture of People's Mandate in Anambra State. In J. Ibrahim, \& O. Ibeanu (Eds.), The 2007 Nigeria Elections and Subversion of Popular Sovereignty. Abuja: Center for Democracy and Development.

Nugent, P. (2001). Winners, Losers and Also Rans: Money, Moral Authority and Voting Patterns in the Ghana 2000 Election. African Affairs, 100, 405-428.

https://doi.org/10.1093/afraf/100.400.405

Nugent, P. (2005). Banknotes and Symbolic Capital; Ghana's Election under the Fourth Republic. A Mimeo, Department of Political Studies, Edinburgh University.

Nwabueze, B. (2003). Election Rigging and Democracy in Nigeria, Being the Conclusion of Two Part Serial. Daily Champion, Wednesday, May, 212003.

Nwabueze, B. O. (1993). The Electoral Process and the 1999 Constitution. In A. Umezulike (Ed.), Democracy beyond the Third Republic. Enugu: Fourth Dimension Publishers.

${ }^{26} \mathrm{Feb} .2013 .(1984)$ 1SCNJ 247. 
Nwolisa, O. B. C. (2007). Electoral Violence and Nigeria's 2007 Elections. Journal of Africa Elections, 6, 155-179. https://doi.org/10.20940/JAE/2007/v6i2a9

Obateru, T. (2008). Reflections on the Jos Crisis. The Vanguard, 6 December 2008.

Omotola, S. (2007). Explaining Electoral Violence in Africa's New Democracies, University of Ilorin. Journal of African Elections, 51-73.

Oshiomhole, A. (2011). Stemming Electoral Violence in Nigeria: A Focus on the Adequacy of the Law and its Enforcement. The Vanguard, Thursday, August 26, 2011.

Propper, K. (2003). The Open Society and its Enemies1966. In B. Nwabueze (Ed.), Daily Champion, Tuesday, May 20, 2003.

Smah, S. O. (2008). Money Politics and Electoral Violence in Nigeria. In V. A. O. Adetula (Ed.), Money and Politics in Nigeria. Abuja: Petra Digital Press.

Umaru, A. (2003). The Constitution and the Electoral Process in Nigeria. Kaduna: Axis Research Agency.

Uzoigwe, G. N. (2007). Democracy on Trial: The Nigeria Federal Elections, 1964-1965. In the $25^{\text {th }}$ Annual Conference of the Association of Third World Studies. 